Pascal Hitzler · Miriam Fernández ·

Krzysztof Janowicz · Amrapali Zaveri .

Alasdair J. G. Gray · Vanessa Lopez .

Armin Haller · Karl Hammar (Eds.)

\title{
The Semantic Web
}

16th International Conference, ESWC 2019

Portorož, Slovenia, June 2-6, 2019

Proceedings

黛 Springer 


\section{Editors}

Pascal Hitzler (ID

Wright State University

Dayton, OH, USA

Krzysztof Janowicz

University of California

Santa Barbara, CA, USA

Alasdair J. G. Gray (D)
Heriot-Watt University
Edinburgh, UK

Armin Haller (iD

The Australian National University

Canberra, ACT, Australia
Miriam Fernández (iD

KMi, The Open University

Milton Keynes, UK

Amrapali Zaveri

Maastricht University

Maastricht, The Netherlands

Vanessa Lopez

IBM Research

Dublin, Ireland

Karl Hammar (iD

Jönköping University

Jönköping, Sweden

ISSN 0302-9743

ISSN 1611-3349 (electronic)

Lecture Notes in Computer Science

ISBN 978-3-030-21347-3

ISBN 978-3-030-21348-0 (eBook)

https://doi.org/10.1007/978-3-030-21348-0

LNCS Sublibrary: SL3 - Information Systems and Applications, incl. Internet/Web, and HCI

(C) Springer Nature Switzerland AG 2019, corrected publication 2019

The chapter "Using Shape Expressions (ShEx) to Share RDF Data Models and to Guide Curation with Rigorous Validation" is Open Access. This chapter is licensed under the terms of the Creative Commons Attribution 4.0 International License (http://creativecommons.org/licenses/by/4.0/). For further details see license information in the chapter.

This work is subject to copyright. All rights are reserved by the Publisher, whether the whole or part of the material is concerned, specifically the rights of translation, reprinting, reuse of illustrations, recitation, broadcasting, reproduction on microfilms or in any other physical way, and transmission or information storage and retrieval, electronic adaptation, computer software, or by similar or dissimilar methodology now known or hereafter developed.

The use of general descriptive names, registered names, trademarks, service marks, etc. in this publication does not imply, even in the absence of a specific statement, that such names are exempt from the relevant protective laws and regulations and therefore free for general use.

The publisher, the authors and the editors are safe to assume that the advice and information in this book are believed to be true and accurate at the date of publication. Neither the publisher nor the authors or the editors give a warranty, expressed or implied, with respect to the material contained herein or for any errors or omissions that may have been made. The publisher remains neutral with regard to jurisdictional claims in published maps and institutional affiliations.

This Springer imprint is published by the registered company Springer Nature Switzerland AG The registered company address is: Gewerbestrasse 11, 6330 Cham, Switzerland 


\section{Ruben Verborgh}

\section{The Function Hub: an implementation-independent read/ write function description repository}

by Ben De Meester, Lander Noterman, Ruben Verborgh, and Anastasia Dimou

Functions are essential building blocks of any (computer) information system. However, development efforts to implement these functions are fragmented: a function has multiple implementations, each within a specific development context. Manual effort is needed handling various search interfaces and access methods to find the desired function, its metadata (if any), and associated implementations. This laborious process inhibits discovery, and thus reuse. Uniform, implementation-independent access is needed. We demo the Function Hub, available online at https://fno.io/hub: a Web application using a semantic interoperable model to map function descriptions to (multiple) implementations. The Function Hub allows editing and discovering function description metadata, and add information about alternative implementations. This way, the Function Hub enables users to discover relevant functions independently of their implementation, and to link to original published implementations.

\section{BibTeX other citation formats}

Published in 2019 in Proceedings of the $16^{\text {th }}$ ESWC: Posters and Demos.

Keywords: Web, reuse, metadata

\section{Read this article online}

- Request a digital copy of this article.

- Comment on this article.

\section{Cite this article in your work}

Cite this article easily using its BibTeX entry:

@inproceedings\{demeester_eswc_demo_2019,

author $=$ De Meester, Ben and Noterman, Lander and Verborgh, Ruben and Dimou, Anastasia\},

Alternatively, pick a reference of your choice below:

IEEE B. De Meester, L. Noterman, R. Verborgh, and A. Dimou, "The Function Hub: an implementation-independent read/write function description repository," in Proceedings of the 16 $6^{\text {th }}$ ESWC: Posters and Demos, 2019.

ACM Ben De Meester, Lander Noterman, Ruben Verborgh, and Anastasia Dimou. 2019. The Function Hub: an implementationindependent read/write function description repository. In Proceedings of the $16^{\text {th }}$ ESWC: Posters and Demos.

LNCS De Meester, B., Noterman, L., Verborgh, R., Dimou, A.: The Function Hub: an implementation-independent read/write function description repository. In: Proceedings of the $16^{\text {th }}$ ESWC: Posters and Demos (2019).

APA De Meester, B., Noterman, L., Verborgh, R., \& Dimou, A. (2019). The Function Hub: an implementation-independent read/write function description repository. In Proceedings of the $16^{\text {th }}$ ESWC: Posters and Demos.

MLA De Meester, Ben, et al. "The Function Hub: an Implementation-Independent Read/Write Function Description Repository." Proceedings of the $16^{\text {th }}$ ESWC: Posters and Demos, 2019. 


\section{Y Discuss this article}

- Discover all publications by Ruben Verborgh.

- Find related articles on Google Scholar.

- Post your questions or comments below.

\section{Comments Ruben Verborgh 1 Login}

ORecommend If Tweet if Share Sort by Oldest

Start the discussion...
LOG IN WITH
OR SIGN UP WITH DISQUS ?
Name

Be the first to comment.

$\triangle$ Subscribe

D Add Disqus to your siteAdd DisqusAdd

Disqus' Privacy PolicyPrivacy PolicyPrivacy

()2012-2019 Ruben Verborgh All text \& images licensed under CC BY 4.0 except where otherwise noted. 